\title{
Improving Students' Motivation and Learning Outcomes Using Edmodo Learning Media Assisted with Meeting Room Media on The Circulation System Materials
}

\author{
Muhammad Wajdi ${ }^{1}$, Nurdiyanti ${ }^{2}$, Nurhasyinah Amir ${ }^{3}$ \\ 1,2,3 Muhamadiyah University of Makassar, Makassar, Indonesia
}

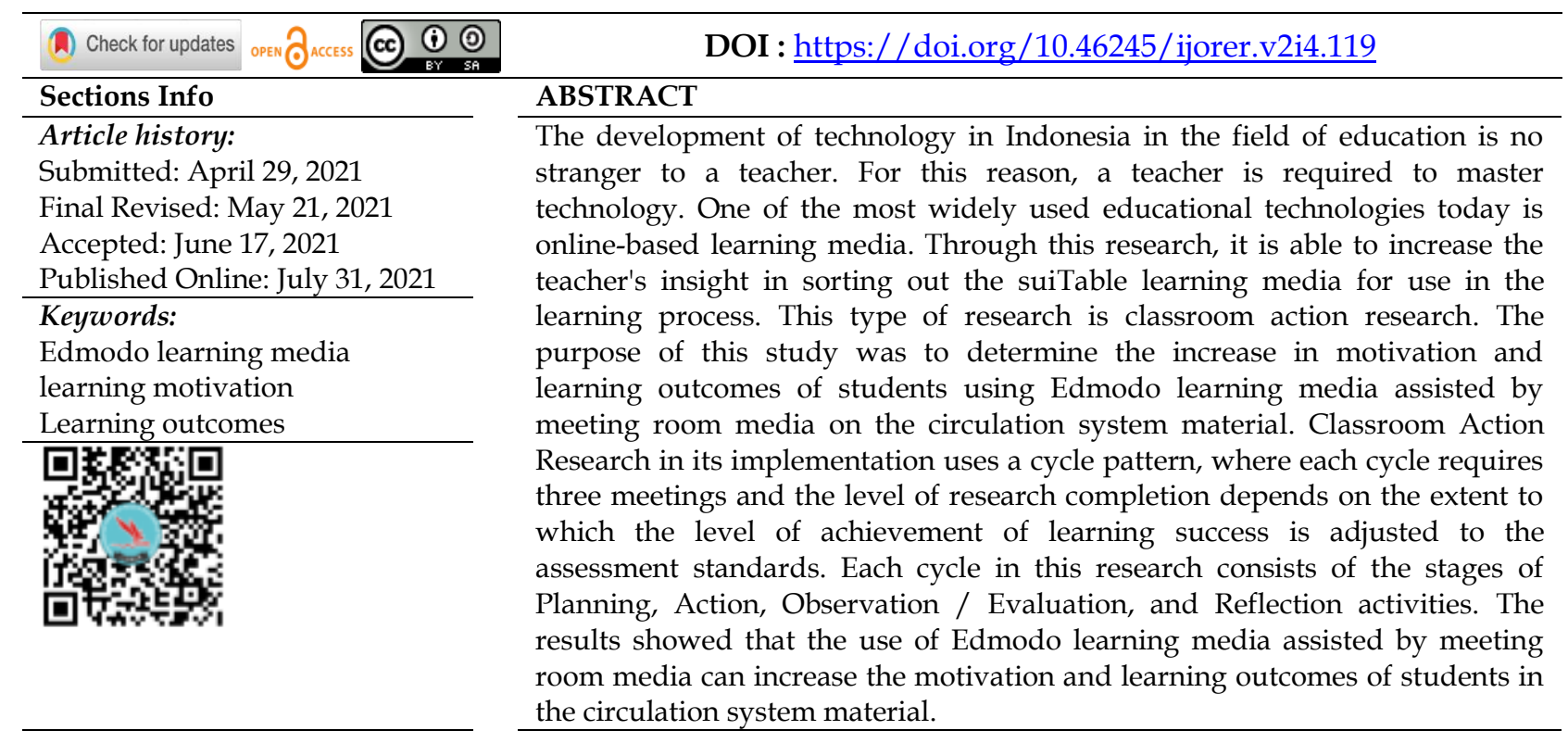

\section{INTRODUCTION}

Education that is based on technological developments in Indonesia creates a new challenge, especially for teachers and prospective teachers in communicating and socializing in learning. Technological developments have created breakthroughs in learning as a new trend in mobile learning (Astra et al., 2015). It change requires the education sector to shift the learning system classroom (Helsa, 2019). Education needs administrators, teachers, and students in the progress of learning and teaching (Enriquez, 2014). The important role of a teacher is to help students learn new concepts and principles in order to be productive in society (Ekici, 2017). Therefore, a teacher must look for suiTable learning methods by looking for what possible assistance will be provided to students in interesting and effective learning (Purnawarman, 2016). In implementing the learning process, it is currently required to adapt to the practice of learning from home through online media (Gunawan et al., 2021). So that students need technology devices that are more up to date and enable them to access knowledge anytime and anywhere (Ekmekci, 2016).

The learning process at National High School 8 Gowa, it can be seen that the teacher only uses the WhatsApp application, the method used by the teacher during the teaching and learning process is only absent and giving assignments without face to face learning on the mobile device screen. This school also implements learning using mobile devices such as smartphones that support the online learning process. Rosyidah (2019) and Safaruddin, et al., (2020) states that learning media are important for fostering motivation and learning outcomes of students, one of which is learning media 
Improving Students' Motivation and Learning Outcomes Using Edmodo Learning Media Assisted With Meeting Room Media on The Circulation System Materials

that is in accordance with the development of Information and Communication Technology (ICT). In its development, electronic learning media is still very rarely used in the world of education, especially in Edmodo learning media (Hikmawan and Sarino, 2018: 80). The use of Edmodo learning media as an online-based learning system encourages implementation to be effective (Pratama, 2017). Edmodo is designed to be very simple, almost similar to Facebook, and provides space for teachers and students, and parents to maximize the teaching and learning process (Kongchan, 2012). The use of this media is expected to be able to increase the motivation and learning outcomes of students in learning.

Edmodo is a social networking media that is prepared for learning for teachers, students, lecturers, and students to create effective, innovative, creative, and fun learning. Using technology such as Edmodo in the classroom provides opportunities for students to submit their results to the teacher without the need for face to face (Shamseternal, 2015). An application that is quite famous and often used in the world is the Edmodo application which is used by millions. Edmodo has several functions in the educational style according to Ainiyah (2015) as, 1) a substitute function, a feature that can be used in scheduling subjects that do not meet enough time face-to-face; 2) Companion function, meaning that students can learn independently about the material that has been delivered by the teacher; 3) Complementary functions, assignment features and quizzes can be used by teachers in offering activity sheets and daily evaluations. In its use Edmodo has several advantages and disadvantages according to Ekayati (2017), namely: 1) Strengths, a) User Interface, by adapting a display like Facebook, it is relatively easy to use even for beginners; b) Compatibility, Edmodo supports various types of file formats such as doc, Swf, ppt, Html, pdf, and others; c) Applications, Edmodo can be accessed via a PC (laptop/desktop) but can also be accessed using an Android based social network. Edmodo application also has drawbacks, namely; a) Social Media, Edmodo cannot connect with various types of social media, in contrast to other applications; b) Language, a language system that still uses international languages, namely English, which results in teachers and students having limited knowledge of English; c) Video Conference, a video conference program that has not been provided makes teachers unable to do face to face online.

Many institutions from Brazil have replaced temporary teaching classes with live streaming technology (Dias et al., 2020: 208) as well as Indonesia. Edmodo does not have video conferencing or live streaming features, so this study also uses meeting room learning media, namely zoom as support. The zoom meeting application is videobased learning used in learning or meetings, seminars, and others (Handayani, 2020). There is a library feature for storing course material, assignment features, quizzes, and discussion forums (Handayani et al., 2021). Edmodo's constraints in mobile learning faced by some students, such as low cellphone battery problems and large storage but do not find difficulties in storing information (Al-Said, 2015).

The use of technology learning media can increase students' self-motivation in learning, thus enabling learning outcomes that can also be increased. Several factors influence learning motivation, namely, internal factors including health; attention; interest; talent; while external factors include, teaching methods; school time; and learning tools. Apart from being one of the factors that determine the direction of attitude, the amount of willingness, and the persistence of student behavior (Keller, 2016). Motivation has determination in a person that makes that person have the effort 
Improving Students' Motivation and Learning Outcomes Using Edmodo Learning Media Assisted With Meeting Room Media on The Circulation System Materials

to do things (Wibowo, 2015). So that teachers need to pay attention to the entire learning process (Ricardo, 2017).

The ability of students to fulfill a stage of achieving a learning experience in a basic competency is called learning outcomes (Ayuwanti, 2016: 107). Raresik (2016: 4) mentions factors that affect learning outcomes from physiological, psychological, social, and non-social environmental aspects. The increase in learning outcomes is marked by the existence of attractive and easy learning media (Nurrita, 2018)

\section{RESEARCH METHOD}

\section{General Background}

The research method used is classroom action research which aims to increase the motivation and learning outcomes of students using Edmodo learning media assisted by meeting room media. This study uses one class that will be controlled by applying Edmodo learning media assisted by meeting room media.

\section{Sample/Participants/Group}

This study used a control class XI Majoring in Mathematics and Natural Sciences 4 as many as 30 students consisting of 23 women and 7 men. The learning process is carried out online through the Edmodo application assisted by the meeting room zoom media.

\section{Instrument and Procedures}

This study, using instruments in the form of learning tools such as lesson plans, multiple-choice test questions totaling 25 numbers used to measure student learning outcomes, as well as learning motivation questionnaires used in measuring students' learning motivation. In general, classroom action research has a design with four main steps, namely planning, implementing, observing/evaluating, and reflecting. The research procedure in this study consisted of 2 cycles. Cycle I will be the basis for researchers in the implementation of cycle II. Each cycle will be given a test question in the form of multiple-choice totaling 25 numbers with a total of 50 questions. Cycle I and cycle II begin after conducting a pre-action test, where this test aims to determine the initial abilities of students. That is, this test is a reference for researchers to increase motivation and learning outcomes that students previously lacked. The results that have been obtained from Cycle I if it is not possible will be continued to the Cycle II stage. Cycle II is the final result of this classroom action research.

\section{Data Analysis}

The type of data in this research is quantitative data. Data analysis techniques are activities carried out using the method of reviewing data obtained from the initial to final meeting. from very lacking to very good using scale 1 to 4 . The data collection techniques researchers use to obtain accurate data are tests and non-tests in the form of observations, interviews, and questionnaires. Descriptive analysis data processing was calculated using Microsoft Excel software and the average value calculated by:

$$
\bar{x}=\frac{\Sigma n}{n}
$$

(Arikunto, 2013)

Information :

$x$ : Mean

In : Sum Score Students

$\mathrm{n}$ : The number of students who have score 
In this study, the scores to measure motivation and learning outcomes are categorized:

Table 1. Score of learning motivation indicator.

\begin{tabular}{cc}
\hline Value & Categories \\
\hline $0-43$ & Very Less \\
$44-51$ & Less \\
$52-63$ & Enough \\
$64-71$ & Good \\
$72-126$ & Very Good \\
\hline
\end{tabular}

(Sudjana, 2009)

Table 2. Categorization of learning outcomes.

\begin{tabular}{cc}
\hline Value & Categories \\
\hline$<75$ & Less \\
$75-83$ & Enough \\
$84-92$ & Good \\
$93-100$ & Very Good \\
\hline
\end{tabular}

(Kementerian Pendidikan dan Kebudayaan, 2017)

The indicators of success in this study are in terms of an increase in the percentage term of learning outcomes that the researcher observes during the learning process. If the percentage of student test results has increased each cycle and is considered complete if it has met the Minimum Completeness Criteria score of 76 or more individuals and $85 \%$ is complete classically.

\section{RESULTS AND DISCUSSION}

Descriptive Analysis of Learning Motivation

The score statistics from the frequency and percentages' distribution obtained show in Table 3.

Table 3. Distribution of frequency and percentage score of learning motivation.

\begin{tabular}{|c|c|c|c|c|c|}
\hline \multicolumn{6}{|c|}{ Learning Motivation } \\
\hline \multirow{2}{*}{ Value } & \multirow{2}{*}{ Categories } & \multicolumn{2}{|c|}{ Frequency } & \multicolumn{2}{|c|}{ Percentage (\%) } \\
\hline & & Cycle I & Cycle II & Cycle I & Cycle II \\
\hline $0-43$ & Very Less & 0 & 0 & 0 & 0 \\
\hline $44-51$ & Less & 0 & 0 & 0 & 0 \\
\hline $52-63$ & Enough & 0 & 0 & 0 & 0 \\
\hline $64-71$ & Good & 1 & 0 & 3 & 0 \\
\hline $72-126$ & Very Good & 29 & 30 & 97 & 100 \\
\hline \multicolumn{2}{|c|}{ Total } & \multicolumn{2}{|c|}{30} & \multicolumn{2}{|c|}{$100 \%$} \\
\hline
\end{tabular}

Descriptive Analysis of Learning Outcomes

At this stage, an initial test was carried out, namely pre-action by the researcher as many as 20 numbers in the form of multiple-choice questions. This test is carried out solely to determine the initial abilities of students before the stages of a cycle I and cycle II are carried out. After a test of learning outcomes has been carried out and analyzed by the researcher, the score statistics from the frequency distribution obtained can be seen in the Table 4. 
Improving Students' Motivation and Learning Outcomes Using Edmodo Learning Media Assisted With Meeting Room Media on The Circulation System Materials

Table 4. Distribution of frequency and percentage score of learning outcomes.

\begin{tabular}{cccccccc}
\hline & & \multicolumn{3}{c}{ Learning Outcomes } & \multicolumn{3}{c}{ Percentage (\%) } \\
\hline \multirow{2}{*}{ Value } & Categories & $\begin{array}{c}\text { Pre- } \\
\text { Action }\end{array}$ & Cycle I & Cycle II & $\begin{array}{c}\text { Pre- } \\
\text { Action }\end{array}$ & Cycle I & Cycle II \\
\hline$<75$ & Less & 30 & 26 & 0 & 100 & 87 & 0 \\
$75-83$ & Enough & 0 & 4 & 11 & 0 & 13 & 37 \\
$84-92$ & Good & 0 & 0 & 16 & 0 & 0 & 53 \\
$93-100$ & Very Good & 0 & 0 & 3 & 0 & 0 & 10 \\
\hline \multicolumn{2}{c}{ Total } & 30 & & & $100 \%$ & \\
\hline
\end{tabular}

This Pre-Action test score is used by researchers as a reference in improving future learning outcomes of students, especially in the circulation system material. Therefore, researchers and teachers need to take action to correct these deficiencies, then proceed to cycle I. The results of the reflection cycle I can be seen in the process of learning biology on the material of the circulation system, there is still a lack of students' attention to biology lessons, this is indicated by students who seek attention in other places. This is because biology learning is carried out using face-to-face online while students are still fixated on learning biology which is just taking notes and accepting assignments given by the teacher through the WhatsApp application, so students are not used to learning like this.

In addition, the network is also a major contributing factor in online learning because some students do not pay attention to the material clearly on the screen, and the availability of an inadequate internet quota from schools, as well as the students' lack of command of the English language. The same thing happened when doing the Cycle I test where there were still many students who did not understand the questions well or lost the opportunity to answer the existing questions.

In fixing the weaknesses that existed in cycle I, the researcher together with the biology teacher-designed learning improvements to cycle II in a more intensive way, namely, explaining the material in-depth and linking it to everyday life; guide students who have difficulty understanding the material; more motivating or encouraging students to learn; notify students in changing the language of the program; as well as giving awards in the form of adding points and praise to students who have successfully answered the questions given by the teacher at the end of the lesson. The implementation of this action, it is expected to improve the learning outcomes of students in cycle II.

The results of reflection in the second cycle stage show the enthusiasm and enthusiasm of students in following the learning process showing progress. Thus, the overall activity at the second cycle stage has increased. Based on the data from the observations that have been made to improve learning cycle II, it is declared successful, because all students have met the completeness criteria. This can be seen in the learning outcomes of cycle II. The success of improving the learning process in cycle II cannot be separated from the reflection carried out between the teacher and researcher in cycle I. Based on the data obtained, it can be said that the learning process in cycle II is declared successful.

Globalization has triggered a tendency to shift in the world of education from conventional face-to-face meetings to a more open education (Budiman, 2017: 32). In 
Improving Students' Motivation and Learning Outcomes Using Edmodo Learning Media Assisted With Meeting Room Media on The Circulation System Materials

accordance with the times, the learning process is developed by optimizing fast ELearning (Monica, 2013). E-Learning is used as a source of online information without having to face to face (Lane, 2016). Previously, E-Learning is used as a complementary medium that only served as a supplement to the learning process in classroom. However, since the pandemic E-learning has become a necessity to continue providing the educational process (Hermawan, 2021).

E-Learning learning innovation is a new model that provides a major role and function for the world of education (Nadziroh, 2017). Various existing information can be accessed easily via the internet network (Hertiavi, 2020). So that the availability of the Internet is an important thing that is used by people in the world in finding information in the world of education. In the internet era, the form of knowledge display and knowledge transmission mode has changed from traditional methods to online platforms (Xie, 2020). New learning styles can produce the main role of learners in reforming traditional teaching and education properly (Ramadiani, 2017). Applications used include E-learning, WhatsApp, Google Classroom, Zoom, and other applications. Temporary data from the results of initial observations found some input, suggestions, and obstacles experienced by teachers and students related to the implementation of online learning (Suryaman, 2020).

The use of Edmodo learning media assisted by meeting room media in the form of zoom in this study can increase the learning motivation of students from cycle I to cycle II. This is because the use of learning media by adjusting the environment can increase the learning motivation of students with updated media (Royani, 2018).

Edmodo is one of the media that looks similar to the Facebook social media account and is practical, flexible, and easy to use (Usman, 2016). The use of Edmodo learning media is assisted by the use of meeting room media in the form of zoom which has video conference or live streaming features. Edmodo itself is known to have no video conferencing or live streaming features. Mahmud (2019) states that the application of Edmodo-based learning media takes place effectively so that students are motivated to take part in learning.

The increase in students' motivation to learn is marked after the teacher and researcher take learning actions. Where the data obtained and analyzed by researchers at the end of the second cycle showed that all students obtained $100 \%$ classical completeness. In addition to learning motivation, the use of Edmodo learning media assisted by meeting room media also improves student learning outcomes because it is equipped with learning activities such as a quiz feature, and assignments and polls (Sudibjo, 2013). Edmodo is more effective because the time to do assignments can be managed in such away. Besides, the use of meeting room media in the form of zoom makes students active in the learning process. In the zoom application, we can communicate with anyone in the form of video (Haqien and Rahman, 2020) In his research to Ismawati and Prasetyo (2020), the use of video conference-based media can support distance learning and make it easier for students to absorb learning material. After taking these actions, at the end of cycle II, it was seen that students were more active in the learning process and learning outcomes also increased. So, based on the indicators of success, there was an increase at the end of cycle II with $100 \%$ classical completeness. 


\section{CONCLUSIONS}

The use of Edmodo learning media assisted by meeting room media can increase students' learning motivation. With the increasing motivation of students in learning, the learning outcomes of students who were previously low then increased significantly. The learning process in each school that supports and facilitates the existence of technological devices can take advantage of Edmodo learning media assisted by meeting room media in the current situation which requires schools to do face-to-face learning. This is done as a form of effort to improve learning on biology and other materials. In future research, as a follow-up to the application, during the learning process, the teacher supervises and guides students in the learning process even though the learning is online.

\section{ACKNOWLEDGEMENTS}

In the production of this article, we would like to wish the principal and teachers of National Senior High School 8 Gowa for allowing us to conduct research in this place. Furthermore, we thank the students of class Majoring in Mathematics and Natural Sciences 4 for being our sample in this study.

\section{REFERENCES}

Ainiyah, Z. (2015). Penggunaan edmodo sebagai media pembelajaran e-learning pada mata pelajaran otomatisasi perkantoran di SMKN 1 Surabaya. Jurnal Pendidikan Administrasi Perkantoran (JPAP), 3(3), 1-13.

Al-Said, K. M. (2013). Students perceptions of edmodo \& mobile learning and their real barriers towards them. The Turkish Online Journal of Educational Technology, 14(2), $167-180$.

Arikunto, S. (2013). Prosedur penelitian suatu pendekatan praktis. Jakarta: PT. Rineka Cipta.

Astra, I. M., Nasbey, H., \& Nugraha, A. (2015). Development of an android application in the form of a simulation lab as learning media for senior high school students. Eurasia Journal of Mathematics, Science, \& Technology Education, 11(5), 1081-1088. doi.org/10.12973/eurasia.2015.1376a

Ayuwanti, I. (2016). Meningkatkan aktivitas dan hasil belajar matematika menggunakan model pembelajaran kooperatif tipe group investigation di SMK Tuma'ninah Yasin Metro. SAP (Susunan Artikel Pendidikan), 1(2), 105-114. doi.org/10.30998/sap.v1i2.1017

Budiman, H. (2017). Peran teknologi informasi dan komunikasi dalam pendidikan. AlTadzkiyyah: Jurnal Pendidikan islam, 8(1), 31-43. doi.org/10.24042/atjpi.v8i1.2095

Dias, M. O., Loper, R. O. A., \& Teles, A. C. (2020). Will virtual replace classroom teaching? Lesson from virtual classes via zoom in the times covid-19. Journal of Advances in Education and Philosophy, 4(5), 208-213. doi.org/10.36348/jaep.2020.v04i05.004

Ekayati, R. (2017). Optimalisasi aplikasi edmodo dalam meningkatkan kemandirian belajar dan kesadaran berbahasa mahasiswa pada mata kuliah literary criticism di FKIP UMSU. Edutech: Jurnal Ilmu Pendidikan dan Ilmu Sosial, 3(1), 153-154. doi.org/10.30596\%2Fedutech.v3i1.992 
Improving Students' Motivation and Learning Outcomes Using Edmodo Learning Media Assisted With Meeting Room Media on The Circulation System Materials

Ekici, D. I. (2017). The use of edmodo in creating an online learning community of practice for learning to teach science. Malaysian Online Journal of Educational Sciences, 5(2), 91-106.

Ekmekci, E. (2016). Integrating edmodo into foreign language classes as an assessment tool. Participatory Educational Research (PER), 1(1), 1-11. doi.org/10.17275/per.16.spi.1.1

Enriquez, M. A. (2014). Students' perceptions on the effectiveness of the use of edmodo as a supplementary tool for learning. DLSU Research Congress, 2(6), 1-6.

Gunawan, G., Kristiawan, M., Risdianto, E., \& Monicha, R. E. (2021). Application of the zoom meeting application in online learning during the pandemic. Education Quarterly Reviews, 4(2), 26.

Handayani, D. (2020). The application of the PjBL model uses whatsapp and zoom meetings in learning. International Journal of Chemistry Education Research, 4(2), 4652. doi.org/10.20885/ijcer.vol4.iss2.art2

Handayani, D., Winarni, E. W., Sundaryono, A., \& Firdaus, M. L. (2021). Implementation of project-based learning model with edmodo application in the capita selecta chemistry course. IJORER: International Journal of Recent Educational Research, 2(2), 184-195. doi.org/10.46245/ijorer.v2i2.90

Haqien, D., \& Rahman, A. A. (2020). Pemanfaatan zoom meeting untuk proses pembelajaran pada masa pandemi covid-19. SAP (Susunan Artikel Pendidikan), 5(1), 51-56. doi.org/10.30998/sap.v5i1.6511

Helsa, Y., \& Kenedy, A. K. (2019). Edmodo-based blended learning media in learning mathematics. Journal of Teaching and Learning in Elementary Education (JTLEE), 2(2), 107-117. doi.org/10.33578/jtlee.v2i2.7416

Hermawan, D. (2021). The rise of e-learning in covid-19 pandemic in private university. IJORER: International Journal of Recent Educational Research, 2(1), 86-95. doi.org/10.46245/ijorer.v2i1.77

Hertiavi, M. A. (2020). Penerapan E-Learning dengan Platform Edmodo untuk Meningkatkan Hasil Belajar Mahasiswa. Jurnal Komunikasi Pendidikan, 4(1), 1-8. Doi.org/ 10.32585/jkp.v4i1.442

Hikmawan, T., \& Sarino, A. (2018). Pemanfaatan media pembelajaran berbasis edmodo terhadap motivasi belajar siswa sekolah menengah kejuruan. MANPER: Jurnal Pendidikan Manajemen Perkantoran, 3(1), 79-86. doi.org/10.17509/jpm.v3i1.9459

Ismawati, D., \& Prasetyo, I. (2020). Efektivitas pembelajaran menggunakan video zoom cloud meeting pada anak usia dini era pandemi Covid-19. Jurnal Obsesi : Jurnal Pendidikan Anak Usia Dini, 5(1), 665-675. doi.org/10.31004/obsesi.v5i1.671

Keller, J. M. (2016). Motivation, learning, and technology: Applying the ARCS-V motivation model. Participatory Educational Research, 3(2), 1-13. doi.org/10.17275/per.16.06.3.2

Kementerian Pendidikan dan Kebudayaan. (2017). Penilaian pendidikan Sistem penilaian hasil belajara dan kemampuan guru melaksanakan penelitian berdasarkan kurikulum 2013. Jakarta: Pusat Penelitian Kebijakan Pendidikan dan Kebudayaan, Balitbang, Kemendikbud,

Kongchan, C. (2012). How a non-digital-native teacher makes use of edmodo. International Conference ICT for Language Learning, 5, 1-4.

Lane, S. (2016). Effective online discussion forums as a legal learning space. American Journal of Educational Research, 4(5), 392-396. doi.org/10.12691/education-4-5-5 
Improving Students' Motivation and Learning Outcomes Using Edmodo Learning Media Assisted With Meeting Room Media on The Circulation System Materials

Mahmud, H., \& Iqbal. (2019). Pembelajaran berbasis edmodo dan motivasi belajar peserta didik di SMKN 2 Palopo. KELOLA: Journal of Islamic Education Management, 4(1), 49-60. doi.org/10.24256/kelola.v4i1.787

Monica, M. (2013). Analysis of perceptions of conventional and e-learning education in corporate training. Journal of Competitiveness, 5(4), 73-79. doi.org/10.7441/joc.2013.04.05

Nadziroh, F. (2017). Analisa Efektifitas Sistem Pembelajaran Berbasis E-Learning. JIKDISKOMVIS: Jurnal Ilmu Komputer dan Desain Komunikasi Visual, 2(1), 1-14.

Nurrita, T. (2018). Pengembangan media pembelajaran untuk meningkatkan hasil belajar siswa. MISYKAT: Jurnal Ilmu-ilmu Al-Quran Hadist Syariah dan Tarbiyah, 3(1), 171-187. doi.org/10.33511/misykat.v3n1.171

Pratama, M. D. W, \& Subroto, W. T. (2017). Pengaruh penggunaan edmodo sebagai media pembelajaran elearning terhadap hasil belajar siswa pada materi pasar modal mata pelajaran ekonomi kelas X SMA. Jurnal Pendidikan Ekonomi (JUPE), 2(2), 1-8.

Purnawarman, P., Susilawati, \& Sundayana, W. (2016). The use of edmodo in teaching writing in a blended learning setting. Indonesian Journal of Applied Linguistic, 5(2), 242-252. doi.org/10.17509/ijal.v5i2.1348

Ramadiani, Azainil, Haryaka, U., Agus, F., \& Kridalaksana, A. H. (2017). User satisfaction model for e-learning using smartphone. 2nd International Conference on Computer Science and Computational Intelligence 2017, 116(1), 373-380. doi.org/10.1016/j.procs.2017.10.070

Raresik, K. A., Dibia, I. K., \& Widiana, I. W. (2016). Analisis faktor-faktor yang mempengaruhi hasil belajar bahasa indonesia pada siswa kelas V SD gugus VI. Mimbar PGSD Undiksha, 4(1), 1-11. doi.org/10.23887/jjpgsd.v4i1.7454

Ricardo, \& Meilani, R. I. (2017). Impak minat dan motivasi belajar terhadap hasil belajar siswa. MANPER: Jurnal Pendidikan Manajemen Perkantoran, 2(2), 188-201. doi.org/10.17509/jpm.v2i2.8108

Rosyidah, Kartini, T., \& Kantun, S. (2019). Penggunaan media edmodo untuk meningkatkan motivasi dan hasil belajar siswa. JURNAL PENDIDIKAN EKONOMI: Jurnal Ilmiah Ilmu Pendidikan, Ilmu Ekonomi Dan Ilmu Sosial, 13(2), 7884.

Royani, I., Falahudin, I., \& Testiani, G. (2018). Pengaruh media edmodo sebagai basis elearning terhadap motivasi belajar siswa pada mata pelajaran IPA. BIOILMI: Jurnal pendidikan, 4(1), 30-34. doi.org/10.19109/bioilmi.v4i1.1734

Safaruddin, Degeng, I. N. S., Setyosari, P., \& Murtadho, N. (2020). The effect of PJBL with WBL media and cognitive style on students' understanding and scienceintegrated concept application. Jurnal Pendidikan IPA Indonesia, 9(3), 384-395. https://doi.org/10.15294/jpii.v9i3.24628

Safaruddin, Juhaeni, R Nurhayati, \& Aulia, N. T. (2020). Konsep Dasar Media Pembelajaran. IEES : Journal of Islamic Education at Elementary School, 1(1).

Shams-Abadi, B. B., Ahmadi, S. D., \& Mehrdad, A. G. (2015). The effect of edmodo on efl learnes' writing performance. International Journal of Educational Investigations, 2(2), 88-97.

Sudibjo, A., \& Wasis. (2013). Penggunaan media pembelajaran fisika dengan e-learning berbasis edmodo blog education pada materi alat optik untuk meningkatkan 
Improving Students' Motivation and Learning Outcomes Using Edmodo Learning Media Assisted With Meeting Room Media on The Circulation System Materials

respons motivasi dan hasil belajar siswa di SMP Negeri 4 Surabaya. Inovasi Pendidikan Fisika, 2(3), 187-190

Suryaman, H., Kusnan., \& Mubarok, H. (2020). Profile of online learning in building engineering education study program during the COVID-19 pandemic. IJORER: International Journal of Recent Educational Research, 1(2), 63-77. doi.org/10.46245/ijorer.v1i2.42

Usman. (2016). Edmodo based e-learning in teaching of english language at department of accounting at polytechnic state of samarinda. Jornal Eksis: Ekonomi, Sosial, dan Bisnis, 12(1), 3295-3298.

Wibowo, K. P., \& Marzuki. (2015). Penerapan model make a match berbantuan media untuk meningkatan motivasi dan hasil belajar ips. Harmoni Sosial: Jurnal Pendidikan IPS, 2(2), 158-169. doi.org/10.21831/hsjpi.v2i2.7667

Xie, X., Zang, Z., \& Ponsoa, J. M. (2020). The Infornation impact of network media, the psychological reaction to the COVID-19 pandemic, and online knowledge acquisition: Evidence from chinese college students. Journal of Innovation $\mathcal{E}$ Knowledge, 5(4), 297-305. doi.org/10.1016/j.jik.2020.10.005

\footnotetext{
${ }^{*}$ Muhammad Wajdi, M.Pd. (Corresponding Author)

Biology Education Department, FKIP

Muhamadiyah University of Makassar

Jl. Sultan Alauddin No 259 Gn. Sari, Makkassar,South Sulawesi ,90221, Indonesia

Email: muh.wajdi@unismuh.ac.id
}

\section{Nurdiyanti, M.Pd.}

Biology Education Department, FKIP

Muhamadiyah University of Makassar

Jl. Sultan Alauddin No 259 Gn. Sari, Makkassar,South Sulawesi ,90221, Indonesia

Email: nurdiyanti@unismuh.ac.id

\section{Nurhasyinah Amir, S.Pd.}

Biology Education Department, FKIP

Muhamadiyah University of Makassar

Jl. Sultan Alauddin No 259 Gn. Sari, Makkassar,South Sulawesi ,90221, Indonesia

Email: nurhasyinaamirr@gmail.com 